\title{
Childhood Mixed Cellularity Classic Hodgkin Lymphoma
}

National Cancer Institute

\section{Source}

National Cancer Institute. Childhood Mixed Cellularity Classic Hodgkin Lymphoma. NCI

Thesaurus. Code C8063.

Mixed cellularity classic Hodgkin lymphoma occurring in childhood. 